\title{
"Obamacare" snagged in legal thicket
}

$\mathrm{W}$

hen officials in more than half the states filed suit against President Barack Obama's landmark health care law, many shrugged it off as a desperate, frivolous attempt by Republicans to achieve in the courts what they failed to do in the United States Congress: block the reforms.

Now, that legal challenge is proving far more potent than simply a case of sour grapes.

Obama's big domestic achievement is almost certainly headed for a showdown in the Supreme Court, an ideologically split body with a narrow conservative majority, following a lower court's decision in Florida declaring the law unconstitutional.

Emboldened by gains in the November 2010 elections, Republicans pressed forward with an effort to repeal the reforms through legislative action. That effort collapsed Feb. 2, when the Senate's Democratic majority defeated a repeal initiative that had passed in the Republican-controlled House of Representatives.

It's a different story in the courts.

At its core, Obama's overhaul seeks to expand health insurance to nearly all Americans through a web of subsidies, controls on the private insurance industry and a federal mandate that people obtain coverage.

It's that mandate that plunged the law into constitutional hot water. "Never before," US District Judge Roger Vinson said in his Jan. 31 ruling, "has Congress required that everyone buy a product from a private company (essentially for life) just for being alive and residing in the United States" (www.flnd.uscourts .gov/announcements/documents/10cv91 doc150.pdf).

Vinson's ruling in Florida was the most consequential of four that have emerged and the second to have gone against what has euphemistically come to be known as "Obamacare." It cer-



"Those who seek to undermine this source of congressional authority would turn back the clock to the hardships of the Great Depression," says Democratic Senator Patrick Leahy of Vermont.

tainly reached the farthest, declaring that the entire law should be tossed because the mandate, which is central to everything else in the Patient Protection and Affordable Care Act, is unconstitutional.

Even so, Vinson kept the law in effect pending appeals and it could take more than a year for the case to filter up to the Supreme Court. Meantime, big healthcare players signaled they will proceed with all requirements. States that joined the suit are among those setting up new insurance markets. Each passing month entrenches the new order more deeply and raises questions about whether it all can really be reset.

At the heart of the challenge is the Constitution's commerce clause, which lets Washington regulate economic activity crossing state lines, and which has been used broadly to exert federal authority over states' rights.

The government argues that a citizen who refuses to buy health insurance, but seeks treatment at the expense of hospital or taxpayers, affects commerce and therefore can be regulated under federal law.
"Those who seek to undermine this source of congressional authority would turn back the clock to the hardships of the Great Depression, striking down principles that have been settled for nearly three-quarters of a century and standing the Constitution on its head," says Democratic Senator Patrick Leahy of Vermont, chairman of the Senate Judiciary Committee.

Leahy earlier told the Senate that, in opting out of health insurance, "free riders do not opt out of the health care market. Rather, they shift the cost of their decision on to people who do have health insurance."

But Michael Carvin, a constitutional attorney, says "sitting at home and staying out of the commercial marketplace is not commerce" and therefore, the government has no business making anyone in that situation buy anything. "If that is proper, then there's literally nothing that Congress can't do." - Cal Woodward, Washington, DC

CMAJ 2011. DOI:10.1503/cmaj.109-3803 